\title{
Textural and Sensory Characteristics of Eel Steaks Processed during Thermal Processing in Brine Medium to Optimize $F_{0}$ Value
}

\author{
Rohini Mugale*, S.B. Patange, V.R. Joshi, G.N. Kulkarni and M.M. Shirdhankar
}

Department of Fish Processing Technology and Microbiology, College of Fisheries, Dr. B. S. Konkan Krishi Vidyapeeth, Ratnagiri - 415629 Maharashtra, India

*Corresponding author

\section{A B S T R A C T}

\begin{tabular}{|l|}
\hline Ke y w o r d s \\
$\begin{array}{l}\text { Eel fish, Brine medium, } \\
\text { Retort pouch, Heat } \\
\text { penetration study, Texture } \\
\text { profile analysis, Sensory } \\
\text { analysis }\end{array}$ \\
\hline Article Info \\
\hline $\begin{array}{l}\text { Accepted: } \\
\text { 10 January 2018 } \\
\text { Available Online: } \\
\text { 10 February 2018 }\end{array}$ \\
\hline
\end{tabular}

\section{Keywords}

Eel fish, Brine medium, penetration study, Texture profile analysis, Sensory

Accepted:

10 January 2018

10 February 2018
Eel (Mastacembelus armatus) steaks in brine processed in four-layered laminated retort pouch was processed in a steam/air mixture overpressure retort at $121^{\circ} \mathrm{C}$. The curry and eel steaks were packed in 60:40 proportion. Time-temperature data from sealed samples was collected during heat processing using a 'Nano Vacq $1 \mathrm{Tc}$ ' data logger to record the data during processing. The product was processed for 2,3 and $4 \mathrm{~min}$ at $121^{\circ} \mathrm{C}$ at the process value of 6.08, 13.89 and 5.03 min respectively. Further, product was analyzed for textural attributes like cohesiveness, toughness, succulence and fibrosity and sensory analysis. These textural attributes decreased as the $F_{0}$ value increased. Based on these analyses, it was observed that, the product processed for $3 \mathrm{~min}\left(\mathrm{~F}_{0}\right.$ value of $\left.13.89 \mathrm{~min}\right)$ with total process time of $50 \mathrm{~min}$ and cook value $99.61 \mathrm{~min}$ gave better textural and sensory characteristics and the product was found satisfactory for the development of eel steaks in brine in retort pouches.

\section{Introduction}

Thermal processing is a method of preserving food by heating in a hermetically sealed containers to eliminate / destroy the microorganism at a given time and temperature (Balachandran, 2001 and Bindu $e t$ al., 2014). Traditionally processed ready-toeat foods packed in tin and aluminium cans have their own disadvantages like higher price of container, development of metallic flavour and discolouration in the product (Vijayan and Balachandran, 1986). With the advent of flexible retort pouch in place of metal cans, the technology of thermal processing has become cost effective as the packaging cost of retort pouch is far lesser than the cost of metal cans. The integral seal maintains an environment in the rigid/flexible container that prevents the growth of other microbes of higher resistance and most importantly it prevents recontaminations from external contaminants and pathogens from producing toxins during storage (Awuah et al., 2007). Xavier et al., (2007) reported the heat penetration characteristics of skipjack tuna in brine packed in TFS and EOE cans. The changes during thermal processing of mackerel in brine medium were reported by Sreenath et al., (2009) and Xavier et al., 
(2013). Further, Biji et al., (2015) observed the changes in green mussel during thermal processing in TFS cans. No information is available on the effects of thermal processing on the nutritional value of eel meat in brine in retort pouch. Therefore, the present study was planned to utilize the freshwater eel for instrumental and sensory characteristics in brine medium during retort pouch processing to optimize $\mathrm{F}_{0}$ value.

\section{Materials and Methods}

\section{Raw material}

Fresh eel were obtained from the Ratnagiri fish market. Fishes were put in ice in the ratio of 1:1 (fish: ice) and transported to laboratory in insulated containers. The fishes were washed thoroughly in potable water and cut into steaks of $4-5 \mathrm{~cm}$ size, using knife. In order to remove slime and blood and increase the firmness of fish muscle during thermal processing, these eel steaks were used for the preparation of eel steaks in brine. The steaks were marinated with garlic ginger and green chilli paste for $30 \mathrm{~min}$ at room temperature.

\section{Retort pouch}

Laminated flexible pouch (4-ply), consisting of 12 micron polyester (outer layer), 9 micron aluminium foil and 15 micron nylon (middle layer) and 70 micron polypropylene (inner cast) was used for packing the fish curry. Pouches $(150 \times 200 \mathrm{~mm})$ used in the present study were purchased from M/s. Pradeep Laminators Pvt. Ltd. Pune, Maharastra, India.

\section{Overpressure retort}

A steam air retort system (KVP Enterprise, $\mathrm{TN}$ ) was used for the experiment. The retort was operated in the steam/air mixture mode during the sterilization cycle. For heat penetration studies pouches were fixed with thermocouple gland through which thermocouples were inserted. Thermocouple output was measured using 'Nano Vacq 1 Tc' data logger to record the data during processing. The retort temperature was maintained at $121{ }^{\circ} \mathrm{C}$ throughout the heating period. After processing the pouches to required $\mathrm{F}_{0}$ value, they were cooled rapidly to prevent overcooking as well as survival of any thermophiles (Ravishankar et al., 2002) till the core temperature of the product reached $55^{\circ} \mathrm{C}$ by pumping water into the retort and recirculating it. On completion of retorting wireless data logger was removed from pouch and recorded dada was analyzed by using software 'Qlever 2 lite' to calculate process value and process time.

\section{Filling and sealing of retort pouch}

The marinated steaks were flash fried and kept aside for $5 \mathrm{~min}$ and packed in retort pouches. About $100 \mathrm{gm}$ fried fish and $150 \mathrm{ml}$ of $2 \%$ brine was filled manually into retort pouches. The pouches were immediately injected with steam to remove air from the filled pouches (Madhawaraj et al., 1992) and sealed immediately using an impulse heat-sealing machine. The sealed pouches were subjected to thermal processing for optimizing process value $\left(\mathrm{F}_{0}\right)$ at process temperature in an overpressure retort. The detailed steps for thermal processing of eel steaks in brine in retort pouch are given in Figure 1.

\section{Thermal process evaluation}

Heat penetration data were plotted on a semi log paper with temperature deficit i.e. Retort temperature - Core temperature (RT-CT) on log scale against time. Slope of heating curve $\left(f_{h}\right)$, time in minutes for sterilization at retort temperature $(\mathrm{U})$, final temperature deficit $(\mathrm{g})$ and cook value $(\mathrm{Cg})$ were determined. The process time (B) was calculated by the formula method (Stumbo, 1973). Total 
process time was determined by adding process time (B) and the effective heating period during come up time i.e. $42 \%$ of comeup time of the product. The $\mathrm{F}_{0}$ value is used as a basis for comparing heat sterilization procedures. It represents the total timetemperature combination received by a food. Among the three different durations (2, 3 and $4 \mathrm{~min}$ ) tried, the product processed for $3 \mathrm{~min}$ was found to have better sensory attributes and textural property and hence samples processing at $121^{\circ} \mathrm{C}$ for $3 \mathrm{~min}$ was chosen for the studies.

\section{Texture profile analysis}

The texture profile analysis (TPA) was performed using a cylindrical probe of $5 \mathrm{~mm}$ diameter fitted with load cell. Eel steaks were cut into $2.5 \mathrm{~cm}$ block for analysis of texture profile. The textural characteristics such as; cohesiveness (ratio of energies expanded in the first and second cycles), toughness, succulence and fibrosity were evaluated after heat penetration study of eel in curry processed at three different durations of processing for 2,3 and $4 \mathrm{~min}$. The product were analyzed based on compression of samples with Texture analyzer (Perten Instrument, Sweden; model TVT-300XP) with TexCal texture analyzer software (version 4.0.2.50), was used to objectively evaluate textural differences between treatments. Uniform size eel steaks samples from processed pouches were used for the analysis. The samples were compressed twice to $40 \%$ of their original height.

\section{Commercial sterility test}

Thermal processed pouches were tested for commercial sterility as per IS 2168:1971. About four pouches selected at random were incubated at $55^{\circ} \mathrm{C}$ for four days and another four were incubated at $37^{\circ} \mathrm{C}$ for 14 days. The incubated pouches were opened aseptically and samples were transferred into sterile thioglycollate broth (HiMedia) tubes. Then a layer of sterile liquid paraffin wax was poured in each test tube to create anaerobic conditions. The tubes were then incubated at $37^{\circ} \mathrm{C}$ for $48 \mathrm{~h}$ and observed for turbidity development, which indicates the survival of microorganisms. The tubes were further incubated for $48 \mathrm{~h}$ to ascertain sterility.

\section{Sensory test}

Sensory analysis was carried out by a 5 member trained sensory panel using a ten point hedonic scale (Vijayan, 1984). A sensory score of 5 was taken as the limit of acceptability.

\section{Statistical analysis}

The data obtained were analyzed by analysis of variance (ANOVA) and when significant differences were found, comparisons among means were carried out by using SNK test.

\section{Results and Discussion}

\section{Standardization of thermal process parameters for eel steaks in brine in retort pouch}

The steaks packed in retort pouch was subjected to thermal processing with three different durations i.e. 2, 3 and 4 min. Heat penetration characteristics of eel steaks in brine processed for 2, 3 and 4 min durations at $121^{\circ} \mathrm{C}$ (Table 1). In all the pouches, the filling weight was maintained at $250 \mathrm{~g}$ per pouch. The sterilization values $\left(\mathrm{F}_{0}\right)$ were estimated to be $6.08,13.89$ and 5.03 respectively. The $\mathrm{F}_{0}$ value recommended for thermal processed fish products ranges from 5 to 20 (Pflug and Christensen, 1980; Frott and Lewis, 1994). These observations were in agreement with the findings of Bindu and Gopal (2008), who observed the $F_{0}$ value of 10 as better for 
smoked tuna in brine processed at different rotation speed. The $\mathrm{F}_{0}$ value of $8 \mathrm{~min}$ for mackerel in brine processed for different retort temperatures at 115,121 and $126^{\circ} \mathrm{C}$ was observed by Xavier et al., (2013). According to Mohan et al., (2014), $\mathrm{F}_{0}$ value of tuna with vegetables in TFS cans was 8 min which was sufficient to get the product with good sensory attributes and commercial sterility. Similarly, the tuna in different filling medium had $\mathrm{F}_{0}$ value of $10 \mathrm{~min}$ (Xavier et al., 2007). It was observed that all the products processed in different filling medium were commercially sterile. Shaikh (2017) noted the $F_{0}$ values of acetes-ball-in-brine as 8.23, 10.88 and 12.82 min respectively.

The come-up time for eel in brine packed in retort pouch to achieve the desired temperature of $121^{\circ} \mathrm{C}$ was found to be 7.05 , 3.31 and $7.51 \mathrm{~min}$ processed for 2,3 and 4 min respectively. However, the cooling period was observed to be 26, 46 and $29 \mathrm{~min}$ for these processing durations. Similar results have been observed by Bindu and Gopal (2008), where the come-up time required to attain $121^{\circ} \mathrm{C}$ was 5-6 min for smoked tuna in brine. Sreenath et al., (2009) reported the come-up time for mackerel in brine processed at different retort temperatures as 6.35, 6.00 and 7.17 respectively. The come-up time required to attain $121{ }^{\circ} \mathrm{C}$ was 3-5 min for mackerel in brine as noted by Xavier et al., (2013). The differences observed in come-up time for various products could be due to variations in the pieces of fish and content of the fish meat packed with brine. In the present study, the slope of heating curve $\left(f_{h}\right)$ value for eel in brine processed for 2,3 and $4 \mathrm{~min}$ at $121^{\circ} \mathrm{C}$ was $11.71,10.54$ and $10.50 \mathrm{~min}$ respectively; there was no significant difference between $f_{h}$ values processed for three different durations. These results agree with the findings of other researcher; wherein the $f_{h}$ value was found to be $20.12 \mathrm{~min}$ for mackerel in brine, $21 \mathrm{~min}$ for mussel in brine and $14.5 \mathrm{~min}$ for prawn in brine processed at $121^{\circ} \mathrm{C}$ for a total process time of 38,43 and 31 min respectively (Mallick et al., 2006). Bindu and Gopal (2008) observed the $f_{h}$ values for different rotation speed as 8.50, 7.50, 7.00 and 7.00 min respectively for tuna in brine. The $f_{h}$ value of thermally processed mackerel in brine processed at different retort temperatures were to be $18.5,17.0$ and $16.5 \mathrm{~min}$ respectively (Xavier et al., 2013).

Cook value $(\mathrm{CV})$ is a parameter for evaluating the impact of thermal processing on food. In the present study, the cook value of eel in brine processed for three different durations of 2, 3 and $4 \mathrm{~min}$ at $121^{\circ} \mathrm{C}$ were $80.53,99.61$ and 54.35 min respectively. Similar observation was made by Sreenath et al., (2009) at different retort temperature $(115,121.1$ and $130{ }^{\circ} \mathrm{C}$ ) for mackerel in brine in TFS cans. The observed cook values were 122.3, 78.0 and $54.5 \mathrm{~min}$ respectively. According to Xavier et al., (2013), the Cg value for mackerel in brine processed at three different retort temperatures as 129.3, 78.77 and 57.28 respectively in TFS cans. Mallick et al., (2006) noted the cook value of mackerel in brine, mussel in brine and prawn in brine processed at $F_{0}$ value 9,8 and 8 to be 92.83 , 95.00 and 69.73 min respectively in TFS cans. The cook value of smoked tuna in brine processed to $F_{0}$ value of 10 in retort pouches with different rotation speed and without rotation speed were 75.61, 60.10, 58.54, 57.86 and $56.00 \mathrm{~min}$ for $\mathrm{F}_{0} 10$ without rotation, $\mathrm{F}_{0}$ 10 for 2, 4, 8 and $10 \mathrm{rpm}$ respectively (Bindu and Gopal, 2008).

The number of minutes required to sterilize at retort temperature (RT) (U) were 6.08, 13.89 and $5.03 \mathrm{~min}$ respectively. The ratio of slope of heating curve to the number of minutes required to sterilize at RT (i.e. $\mathrm{f}_{\mathrm{h}} / \mathrm{U}$ ) values were $1.57,1.20$ and 1.45. The final temperature deficit $(\mathrm{g})$ values for eel fish in curry were $0.74, \quad 0.59$ and $0.52 \mathrm{~min}$ 
respectively. The process time (B) for eel in brine processed for $\mathrm{F}_{0}$ value of $6.08,13.89$ and $5.03 \mathrm{~min}$ at processing temperature of $121^{\circ} \mathrm{C}$ was $21.02,13.34$ and $12.24 \mathrm{~min}$ respectively. Similarly, Mallick et al., (2006) observed the $\mathrm{B}$ value for mackerel in brine, mussel in brine and prawn in brine in TFS cans at $121^{\circ} \mathrm{C}$ to be $35.57,38.02$ and $25.86 \mathrm{~min}$ respectively. Sreenath et al., (2009) reported the process time values to be 56,29 and $10 \mathrm{~min}$ for mackerel in brine in TFS cans processed at $115,121.1$ and $130^{\circ} \mathrm{C}$ respectively. According to Bindu and Gopal (2008), the process time values were 29.46, 22.47, 20.35, 19.72 and 18.12 min for tuna in brine without and with rotating speed for processed in retort pouch. Xavier et al., (2013) noted the process time values as 49.60, 28.31 and $18.24 \mathrm{~min}$ for mackerel in brine in TFS cans processed at 115,121 and $126^{\circ} \mathrm{C}$ respectively. It can be concluded that the process time for different fish products packed in brine as a filling medium greatly varied owing to the type of the product and different processing temperature. The total process time (TPT), which was found out by adding $42 \%$ of CUT to $B$ varied significantly with change in sterilization value and it was 52.30, 50.01 and $50.66 \mathrm{~min}$ for eel in curry processed at $121^{\circ} \mathrm{C}$ for 2,3 and $4 \mathrm{~min}$ respectively. Heat penetration characteristics of thermally processed eel steaks in brine in retort pouch processed to different durations are presented in Figure 2, 3 and 4.

\section{Texture profile analysis}

The results of TPA of eel steaks in curry processed for 2, 3 and $4 \mathrm{~min}$ (Fig. 5). The toughness/hardness for $F_{0}$ values of 6.08 , 13.89 and $5.03 \mathrm{~min}$ was $2.25 \pm 0.13$, $2.70 \pm 0.27$ and $2.26 \pm 0.14 \mathrm{~J}^{\mathrm{m}} \mathrm{m}^{-3}$. It is observed from the result that the toughness decreased as $F_{0}$ values increased ( $\left.p>0.05\right)$. This may be due to the effect of prolonged heat treatment on breakdown of connective tissue protein leading to softness of the muscle. The values obtained for cohesiveness for eel in curry were $0.27 \pm 0.01,0.42 \pm 0.02$ and $0.24 \pm 0.02$ for 6.08 , 13.89 and 5.03 min respectively and showed no significant difference $(\mathrm{p}>0.05)$ when $\mathrm{F}_{0}$ increased. Succulence which indicated the tenderness/juiciness of the product is expressed as g/area. The succulence values obtained for eel in brine for $\mathrm{F}_{0}$ values of 6.08, 13.89 and 5.03 min 2.58, 2.94 and 2.53 g/area. The succulence values for $4 \mathrm{~min}$ processed product were lesser than the 3 min product which indicated over-processing of the eel in brine product. Fibrosity is the characteristic of textural quality of food products being fibrous. The values of fibrosity for eel in brine processed for different $F_{o}$ values of 6.08, 13.89 and 5.03 at $121^{\circ} \mathrm{C}$ were $7.74,8.03$ and 7.15. The result showed no significant difference in the fibrosity value of eel meat processed at different durations ( $p>0.05)$. The changes observed in textural characteristics of raw and processed mussel meat in brine in TFS cans during thermal processing were observed by Biji et al., (2015). After processing there were significant changes in the toughness/hardness mainly due to heat processing which caused conversion of collagen to gelatin and dissociation of muscle protein (Bindu et al., 2007). Cohesiveness of raw and processed sample decreased from 0.24 in raw mussel meats to 0.16 in thermal processed samples.

Xavier et al., (2007) reported the changes in textural characteristics of tuna in brine in TFS cans during thermal processing. After processing the hardness/firmness of precooked tuna meat decreased from 5.67 to $4.63 \mathrm{kgf}$ in tuna in brine. Cohesiveness of precooked tuna meat and thermal processed tuna meat increased from 0.28 to 0.37 respectively. This value is an indication of internal bonding of the muscle. Compared to precooked tuna, samples after processing showed higher values because of heat processing. 
Table.1 Heat penetration characteristics of eel steaks in brine processed at $121^{\circ} \mathrm{C}$

\begin{tabular}{|c|l|c|c|c|}
\hline Sr. No. & Heat penetration & \multicolumn{3}{|c|}{ Processing duration } \\
\cline { 3 - 5 } & Characteristics & $\mathbf{2}$ min & $\mathbf{3}$ min & $\mathbf{4}$ min \\
\hline $\mathbf{1}$ & $\mathrm{F}_{\mathrm{o}}$ & $6.08 \pm 0.28$ & $\mathbf{1 3 . 8 9} \pm \mathbf{0 . 6 8}$ & $5.03 \pm 0.42$ \\
\hline $\mathbf{2}$ & $\mathrm{f}_{\mathrm{h}}$ & $11.71 \pm 0.35$ & $\mathbf{1 0 . 5 4} \pm \mathbf{0 . 7 1}$ & $10.50 \pm 0.30$ \\
\hline $\mathbf{3}$ & $\mathrm{U}$ & $6.08 \pm 0.28$ & $\mathbf{1 3 . 8 9} \pm \mathbf{0 . 6 8}$ & $5.03 \pm 0.42$ \\
\hline $\mathbf{4}$ & $\mathrm{f}_{\mathrm{h}} / \mathrm{U}$ & $1.57 \pm 0.21$ & $\mathbf{1 . 2 0} \pm \mathbf{0 . 1 0}$ & $1.45 \pm 0.27$ \\
\hline $\mathbf{5}$ & $\mathrm{g}{ }^{\circ} \mathrm{C}$ & $0.74 \pm 0.05$ & $\mathbf{0 . 5 9} \pm \mathbf{0 . 0 3}$ & $0.52 \pm 0.02$ \\
\hline $\mathbf{6}$ & $\mathrm{Cg}(\mathrm{min})$ & $21.02 \pm 0.01$ & $\mathbf{9 9 . 6 1} \pm \mathbf{1 . 4 1}$ & $54.35 \pm 4.04$ \\
\hline $\mathbf{7}$ & $\mathrm{B}(\min )$ & $\mathbf{1 3 . 3 4} \pm \mathbf{0 . 6 1}$ & $12.24 \pm 0.52$ \\
\hline $\mathbf{8}$ & $\mathrm{CUT}$ & $7.05 \pm 0.62$ & $\mathbf{3 . 3 1} \pm \mathbf{0 . 4 9}$ & $7.51 \pm 0.32$ \\
\hline $\mathbf{9}$ & $\mathrm{TPT}$ & $52.3 \pm 1.45$ & $\mathbf{5 0 . 0 1} \pm \mathbf{5 . 7 7}$ & $50.66 \pm 2.96$ \\
\hline
\end{tabular}

(All values are expressed as mean \pm standard error)

$\mathrm{F}_{0}$ - Sterilization value, fh- slope of heating curve, U- Time in min for sterilization at retort temperature, g- Final temperature, B- Process time, CUT- Come up time, Cg- Cook value, TPT- Total process time

Fig.1 Thermal processing of eel steaks in brine

Raw material (fresh whole eel fish)

Washed thoroughly in potable water

Dressing of fish (removal of head, fin \& gut) then cut into $4-5 \mathrm{~cm}$ steaks

Flash fried in refined oil for $5 \mathrm{~min}$ and kept aside

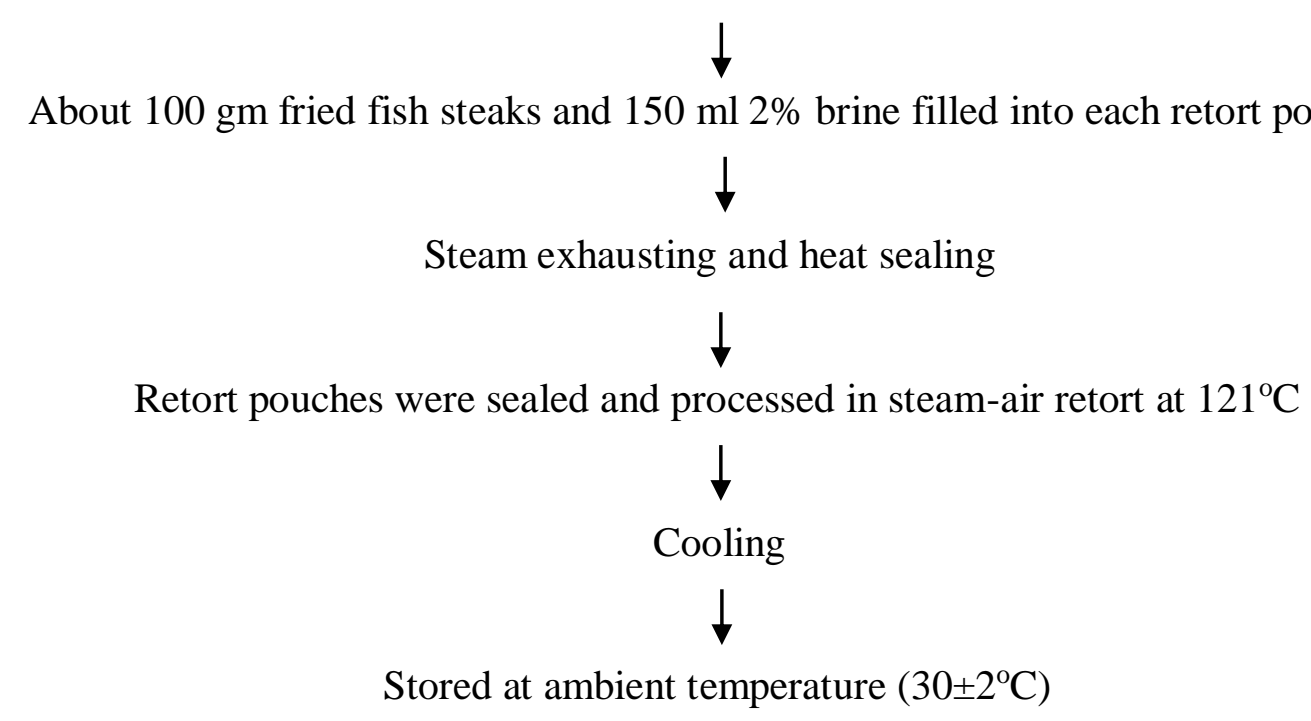


Fig.2 Heat penetration characteristics of eel steaks in brine processed for $2 \mathrm{~min}$

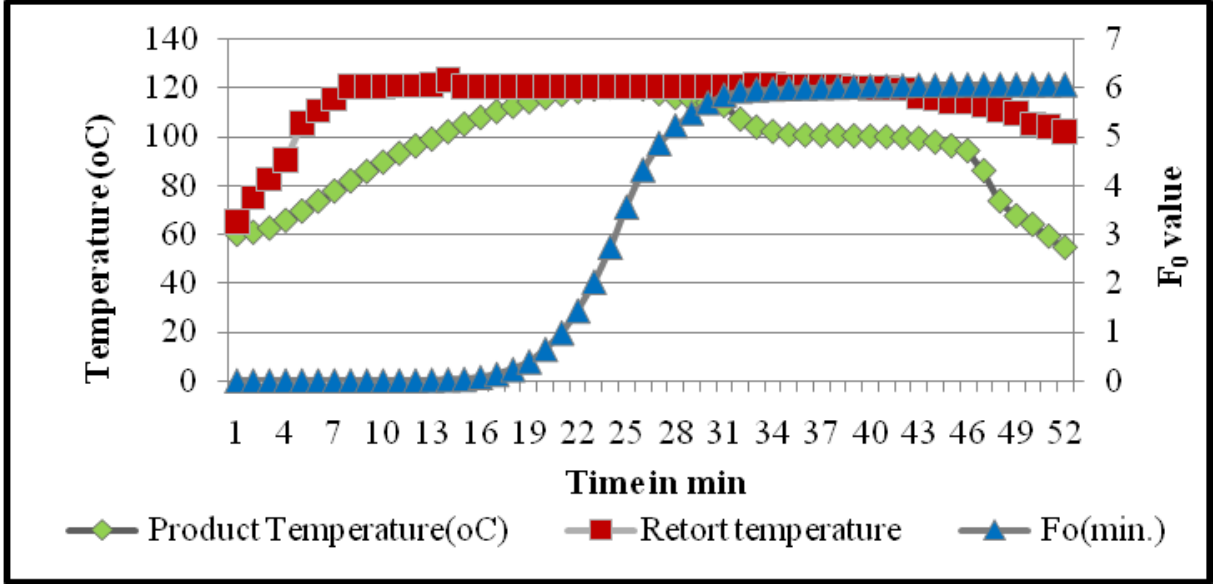

Fig.3 Heat penetration characteristics of eel steaks in brine processed for $3 \mathrm{~min}$

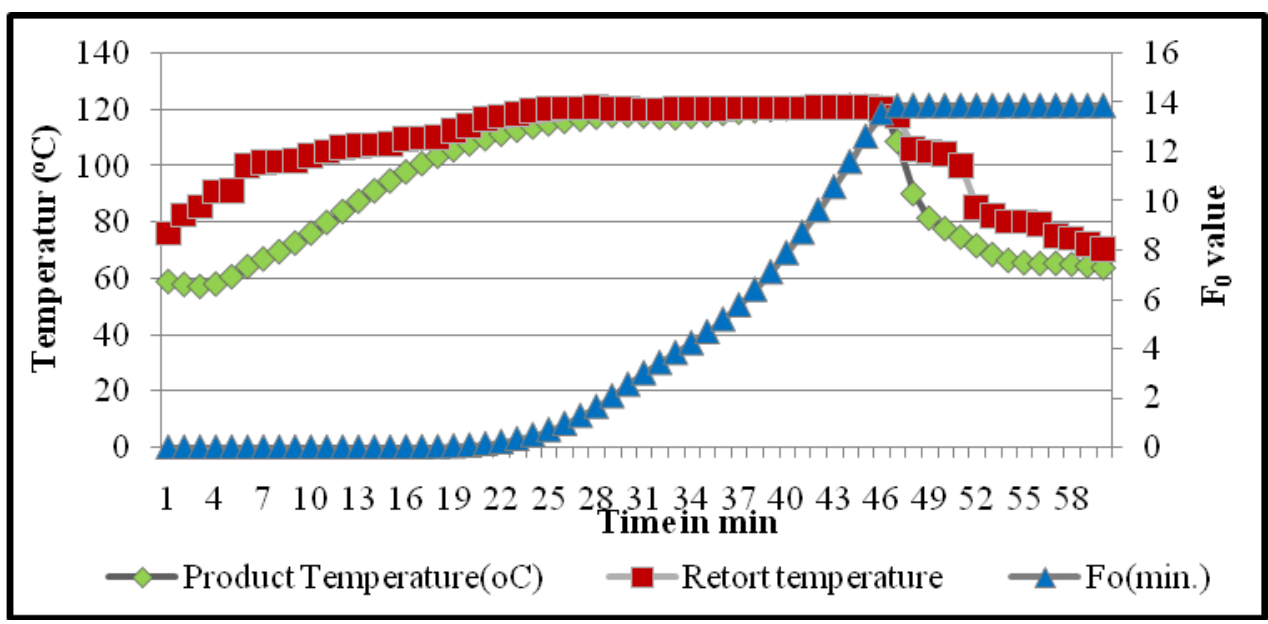

Fig.4 Heat penetration characteristics of eel steaks in brine processed for $4 \mathrm{~min}$

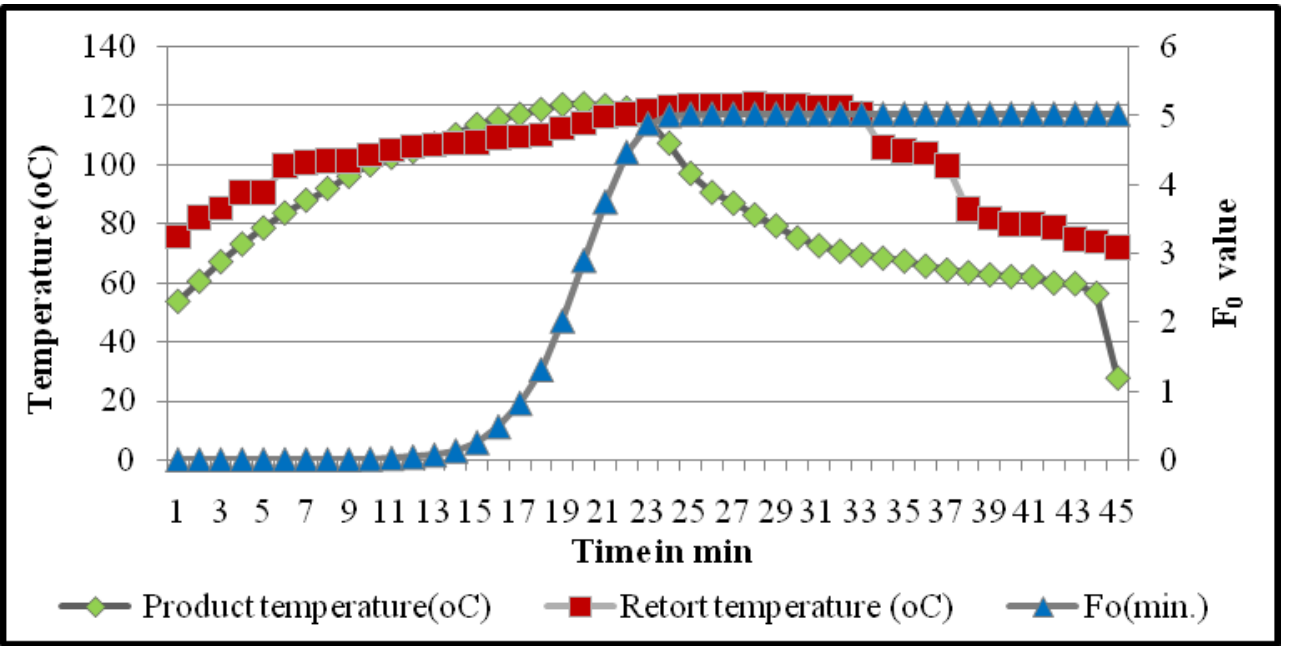


Fig.5 Texture profile attributes of eel steaks in brine processed for 2,3 and 4 min at $121^{\circ} \mathrm{C}$

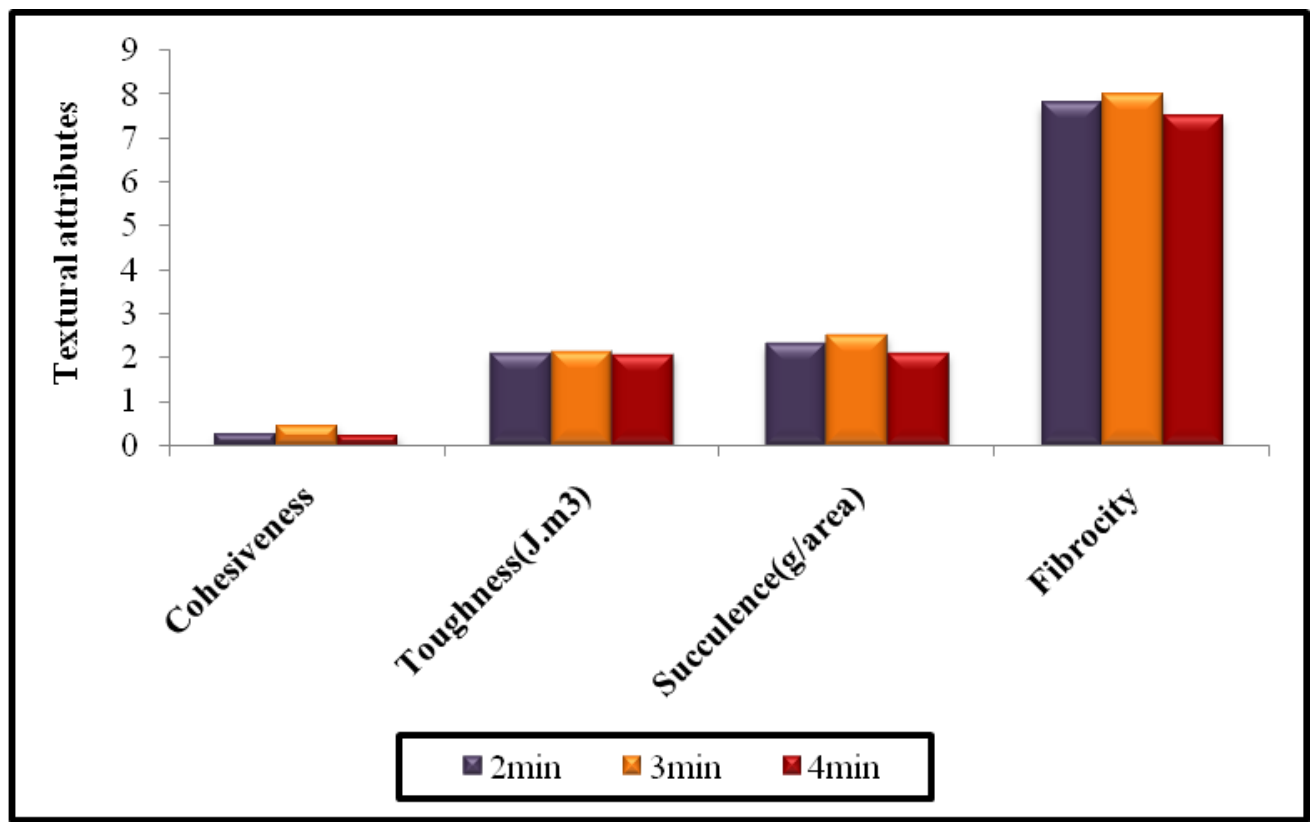

Fig.6 Sensory characteristics of eel steaks in brine processed for 2,3 and 4 min at $121^{\circ} \mathrm{C}$

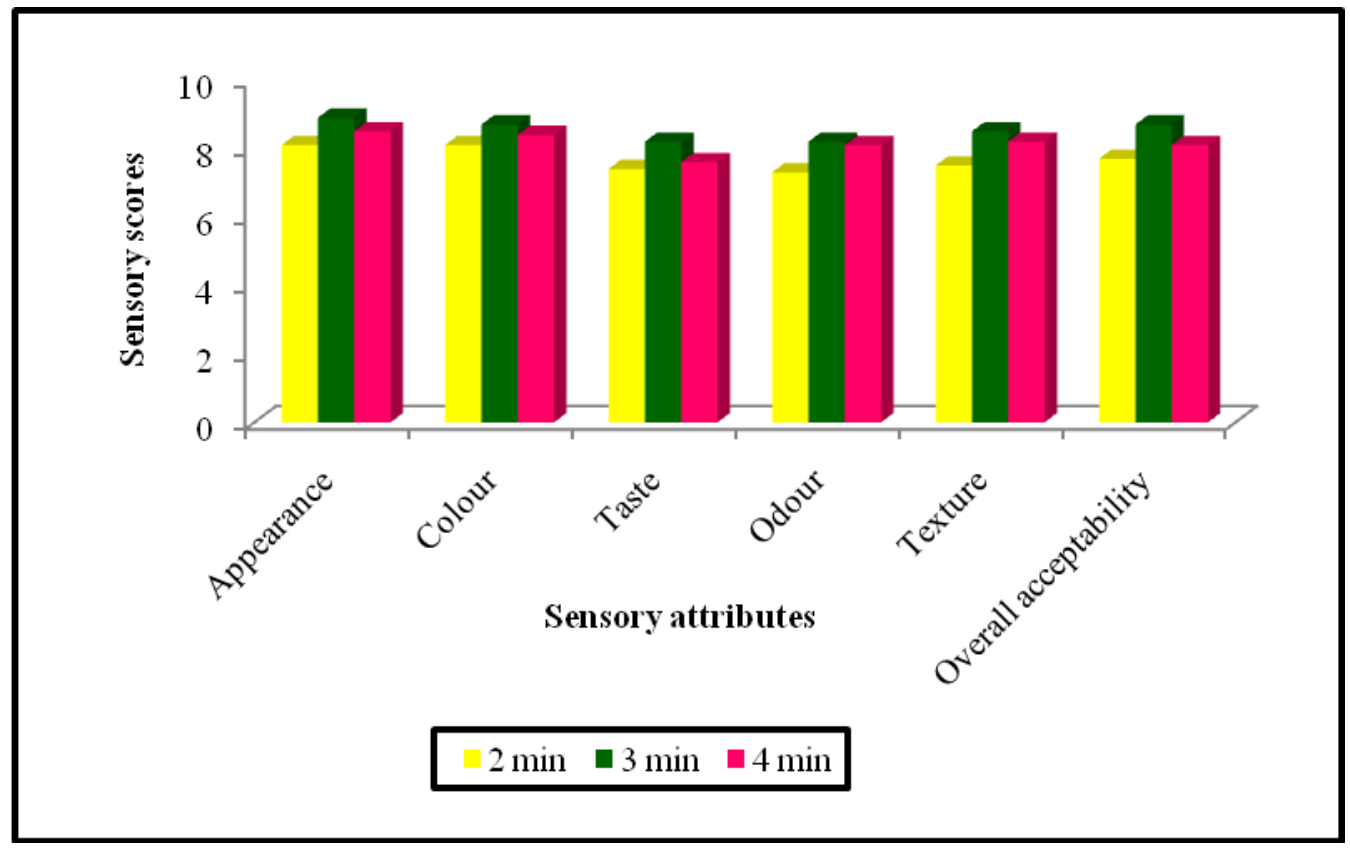

Xavier et al., (2013) observed the changes during thermal processing of mackerel in brine medium. Cohesiveness value of fresh mackerel decreased during brining and increased after precooking. During thermal processing, cohesiveness value of 0.28 was obtained for mackerel processed at $115^{\circ} \mathrm{C}$ Mackerel processed at $121^{\circ} \mathrm{C}$ had reduced cohesiveness value of 0.25 than the value obtained for $115^{\circ} \mathrm{C}$. At higher retort temperature viz., $126^{\circ} \mathrm{C}$ reduced cohesiveness value of 0.20 was noted. The cohesiveness of 
thermally processed foods decreased with increasing temperatures (Ma et al., 1983). Similar observations were recorded in the present study.

\section{Sensory analysis}

The sensory scores observed in the present study, indicated that the overall acceptability scores for eel in curry processed for 12.89 min gave higher values as compared to product processed for 5.19 and $16.75 \mathrm{~min}$ (Fig. 6). Significant effect was observed on colour of the product. The sensory scores for colour was 8.3 for 12.89 min which was higher than 5.19 (7.4) and 16.75 (7.5) $\mathrm{min}$ processed product. Similarly, score given for test attribute by taste panel was 8.3 for 12.89 min which was higher than 5.19 min (score 7.8) and $16.75 \mathrm{~min}$ (7.6) processed product. The sensory scores for odour was 9.0 for $12.89 \mathrm{~min}$ which was also higher than 5.19 (8.5) and 16.75 (8.2) $\mathrm{min}$. The scores for texture was 8.4 for $12.89 \mathrm{~min}$ which was higher than 5.19 (7.3) and 16.75 (7.2) min. The sensory scores for colour was 8.7 for 13.89 min which was higher than 6.08 (8.1) and 5.03 (8.4) min processed eel steaks in brine medium. Similarly, score for taste was 8.2 for 13.89 min which was higher than 6.08 min (score 7.4) and $5.03 \mathrm{~min}$ (7.6) processed product. The sensory scores for odour was 8.2 for 13.89 min which was higher than 6.08 (7.3) and $5.03(8.1) \mathrm{min}$. The scores for texture was 8.5 for 13.89 min which was higher than 6.08 (7.5) and $5.03(8.2) \mathrm{min}$.

Sensory evaluation was performed by Sreenath et al., (2009) for mackerel in brine processed at $F_{0}$ value of $8 \mathrm{~min}$ at different retort temperature of 115,121 and $130^{\circ} \mathrm{C}$. The sensory score for colour was 6.87, 7.53 and 8.28 respectively. Whereas, for flavour it was $7.21,7.24$ and 7.33 respectively. The overall acceptability score for mackerel in brine was 7.17, 7.64 and 8.46 respectively. Mohan et al., (2014) investigated sensory characteristics of tuna with different vegetables in brine processed for $F_{0}$ value of $8 \mathrm{~min}$. Sensory scores for appearance for all the vegetable packed samples were 8.51, 8.78, 8.63, 8.65 and 8.67 respectively. Similarly, the scores for texture were $8.63,817,8.48,6.62$ and 7.31 respectively; for taste were $8.11,8.46,8.23$, 7.77 and 8.21 respectively. The score for overall sensory acceptability for all the vegetable packed samples were 8.41, 8.35, $8.40,7.61$ and 8.02 respectively.

Sensory score for mackerel in brine processed at different retort temperatures were noted by Xavier et al., (2013). The sensory scores for colour of the product were 7.0, 7.49 and 8.1 respectively. Similarly, the sensory scores for flavor were 7.4, 7.6 and 7.9 respectively. In case of overall acceptability, the sensory score for mussel in brine processed at different retort temperature for an $\mathrm{F}_{0}$ value of 8 were 7.2, 7.8 and 8.4 respectively. Biji et al., (2015) performed the sensory evaluation of green mussel in brine processed at $121.1^{\circ} \mathrm{C}$ in TFS cans. Sensory score for appearance for mussel in brine was 8.3, for colour it was 7.5 and for flavour sensory 7.7, for odour 7.5. In case of taste and overall acceptability the sensory score was 7.5 and 7.5 respectively. It can be concluded that for the product processed the recommended levels of process values (i.e.5 to 13 ) were able to score higher sensory attributes with retention of nutritional quality and commercial sterility.

The eel steaks in brine processed for three different durations of 2,3 and 4 min with an $\mathrm{F}_{0}$ values of $6.08,13.89$ and 5.03 min were commercially sterile, based on the commercial sterility, sensory evaluation and texture profile analysis, $\mathrm{F}_{0}$ value of $13.89 \mathrm{~min}$ for 3 min duration with a cook value of 99.61 and total process time of $50.01 \mathrm{~min}$ was found satisfactory for the preparation of eel steaks in brine in retort pouches. 


\section{References}

Awuah, G. B., Ramaswamy, H. S. and Economodes, A. 2007. Thermal processing and quality: Principles and overview. Chem. Engg. Processing, 46: 584-602.

Balachandran, K.K. 2001. Freezing. In: PostHarvest Technology of Fish and Fish Products. Daya publishing house, New Delhi, 288-307.

Biji, K. B., Shamseer, R. M., Mohan, C. O., Ravishankar, C. N., Mathew, S. and Gopal, T. K. S. 2015. Effect of thermal processing on the biochemical constituents of green mussel (Perna viridis) in tin-free-steel cans. J. Food Sci. Technol., 52(10): 6804-6809.

Bindu, J. and Gopal, T. K. S. 2008. Heat penetration characteristics of smoked tuna in oil and brine in retort pouches at different rotational speeds. J. Food Process. Preserv. 32: 23-246.

Bindu, J., Mallick, A. K. and Gopal, T. K. S. 2014. Thermal processing of fishery products in flexible and rigid containers. Fish. Technol., 51: 137-148.

Bindu, J., Ravishankar, C. N. and Srinivasa, T. K. G. 2007. Shelf life evaluation of ready-to eat black clam (Villorita cyprinoides) product in indigenous retort pouches. J. Food Engg., 78: 9951000 .

Frott R, and Lewis A. S. 1994. In: R. Frott and AS lewis (Eds) Canning of meat and Fish Products (202). UK: Chapman and Hall.

IS 2168 1971. Specification for pomfret canned in oil. Indian Standards Institute, New Delhi, India.

Ma, L. Y., Deng, J. C., Ahmed, E. M. and Adams, J. P. 1983. Canned shrimp texture as a function of its heat history. J. Food Sci., 48: 360-363.

Madhawaraj, M. S., Sathish, H. S., Rao, A. R. V., Rao, G. C. P. R. and
Mahendrapandian, S. 1992. Steam-flush water seal technique for removal of headspace air in retort pouches to near zero levels. Lebensm. Wiss. U. Technol., 25: 87.

Mallick, A. K., Gopal, T. K. S., Ravishankar, C. N. and Vijayan, P. K. 2006. Canning of rohu (Labeo rohita) in north Indian style curry medium using polyestercoated tin free steel cans. Food Sci. Technol. Int., 12(6): 539-545.

Mohan, C. O., Remya, S., Ravishankar, C. N., Vijayan, P. K. and Srinivasa Gopal, T. K. 2014. Effect of filling ingredient on the quality of canned yellowfin tuna (Thunnus albacares). Intl. J. Food Sci. Technol. 49: 1557-1564.

Pflug, I. J. and Christensen, R. 1980. Converting an F-value determined on the basis of one z-value to an F-value determined on the basis of another $\mathrm{z}$ value. J. Food Sci., 45(1): 30-35.

Ravishankar, C. N., Gopal, T. K. S. and Vijayan, P. K. 2002. Studies on heat processing and storage of seer fish curry in retort pouches, Packag. Technol. Sci. 15: 3-7.

Shaikh, S. M. 2017. Thermal processing of acetes balls in retort pouch. Ph.D thesis, Dr. Balasaheb Sawant Konkan Krishi V idhyapeeth, Dapoli, Maharashtra, 1-235.

Sreenath, P. G., Abhilash, S., Ravishankar, C. N., Anandan, R. and Srinivasa Gopal, T. K. 2009. Heat penetration characteristics and quality changes of Indian mackerel (Rastrelliger kangurta) canned in brine at different retort temperatures. J. Food Process. Engg., 32: 893-915.

Stumbo, C. R. 1973. Thermobacteriology in Food Processing, $2^{\text {nd }}$ edn., 236, Academic Press. Inc. New York.

Vijayan, P. K. 1984. Report on training programme on retortable pouch processing of fish and fish analysis at Tropical Development and Research 
Institute and Metal Box (R\&D), UK, Cochin: Central Institute of Fisheries Technology.

Vijayan, P. K. and Balachandran, K. K. 1986. Development of canned fish curry. Fish. Technol., 23, 57-60.

Xavier, K. A. M., Ravishankar, C. N., Bindu, J. and Gopal, T. K. S. 2013. Textural and colour changes of mackerel (Rastrelliger kanagurta) thermal processed at different retort temperatures. Fish. Technol., 50:133138.

Xavier, K. A. M., Sreenath, P. G., Sil, S., Ravishankar, C. N., Bindu, J. and Gopal, T.K.S. 2007. Effect of filling media on heat penetration characteristics and texture of skipjack tuna (Katsuwonis pelamis) in indigenous polymer coated easy open end tin free steel cans. Fish. Technol. 44(2): 159-166.

\section{How to cite this article:}

Rohini Mugale, S.B. Patange, V.R. Joshi, G.N. Kulkarni and Shirdhankar, M.M. 2018. Textural and Sensory Characteristics of Eel Steaks Processed during Thermal Processing in Brine Medium to Optimize $\mathrm{F}_{0}$ Value. Int.J.Curr.Microbiol.App.Sci. 7(02): 849-859. doi: https://doi.org/10.20546/ijcmas.2018.702.107 